\title{
The effect of cyanobacterial blooms on bio- and functional diversity of zooplankton communities
}

\author{
Wojciech Krztoń ${ }^{1}$ (D) Joanna Kosiba ${ }^{1}$ (D) . Agnieszka Pociecha ${ }^{1}$. \\ Elżbieta Wilk-Woźniak ${ }^{1}$ (i)
}

Received: 3 September 2018 / Revised: 26 March 2019 / Accepted: 29 March 2019 /

Published online: 10 April 2019

(C) The Author(s) 2019

\begin{abstract}
Global biodiversity decline is believed to be caused by high anthropopressure. Particularly vulnerable habitats are freshwater ecosystems, which are hotspots of biodiversity. The threat to these ecosystems are cyanobacterial blooms, which tend to proliferate in the face of climate changes. Cyanobacteria development and dominance affect the whole food web, especially the zooplankton community. We used three classical biodiversity indexes (species richness, Simpson's Diversity Index and Shannon Diversity Index) and three functional diversity indexes (functional richness, functional evenness and functional divergence) to study the impact of cyanobacterial bloom on the zooplankton community. The study was conducted in water bodies with a different period of bloom duration (short-lasting blooms vs. long-lasting blooms) in order to determine the impact of the proliferated blooms on the aquatic ecosystems. Use of functional diversity indexes allowed for identifying changes that can be overlooked by classical biodiversity indexes. We conclude that cyanobacterial bloom involves modifications of functional trait space of studied communities and, in consequence, functioning of aquatic ecosystems.
\end{abstract}

Keywords Aquatic ecology $\cdot$ Biodiversity $\cdot$ Ecosystem functioning $\cdot$ Trait-based approach

\section{Introduction}

It is widely accepted that the current geological period is called 'Anthropocene' due to human activity (Crutzen 2006). High anthropopressure leads to the loss of global biodiversity known as the 'Sixth extinction' (Barnosky et al. 2011). Because of that, all ecosystems are threatened, but the freshwaters experience declines in biodiversity far greater than the terrestrial one. Covering only $0.8 \%$ of the Earth's surface, these ecosystems support almost $6 \%$ of species (Dudgeon et al. 2006).

Communicated by Anurag chaurasia.

Wojciech Krztoń

krzton@iop.krakow.pl

1 Institute of Nature Conservation, Polish Academy of Sciences, al. Adama Mickiewicza 33, 31-120 Kraków, Poland 
The high risk and threat to freshwater ecosystems are from cyanobacterial blooms. Thanks to numerous adaptations e.g., higher temperature optimum compared to other phytoplankton groups (Paerl and Huisman 2008), cyanobacteria tend to develop better in a changing world and phenomena such as global warming, heat waves and eutrophication (e.g. O'neil et al. 2012). Developing in mass, cyanobacteria create phenomena called water 'blooms' which impact many aspects of aquatic ecosystems, affecting the processes conducted by organisms dwelling in these habitats (Havens 2008). A particularly vulnerable group to cyanobacterial blooms is zooplankton, which is inseparably related to phytoplankton.

Planktonic animals may be affected by the presence of cyanobacteria in many ways (Ger et al. 2016). Cyanobacterial blooms are believed to be a stress that cause a decrease of biodiversity in water ecosystems due to numerous inhibitory effects on zooplankton (Paerl and Otten 2013) as, for example, toxins production (Tillmanns et al. 2008) or poor nutritional values or morphology (Wilson et al. 2006). Large colonies or long trichomes cause difficulties in the nourishing of animals and may cause mechanistic damages of feeding apparatus (Wejnerowski et al. 2015). In such a way, bloom events may affect the functioning of freshwater ecosystems by modification of zooplankton biodiversity (Kosiba et al. 2018). Some studies indicate that the stability of freshwater ecosystems (Thompson and Shurin 2012) is related to the higher biodiversity of zooplankton, however the complexity of processes in ecosystems imply difficulties in predicting loss of biodiversity.

The studies of Barnett et al. (2007) and Litchman et al. (2013) suggest that use of traitbased methods may improve our understanding of the processes determining the diversity of zooplankton communities. Biodiversity is clearly related to ecosystem functioning (Hooper et al. 2005), however not simply by species richness and composition but via their functional traits which influence ecological processes (Schmera et al. 2017). Classicallyused indexes for measurement of biodiversity treat all of the species and individuals as equal (Mouchet et al. 2010), which leads to an underestimation of aspects of diversity which affect ecosystem properties (Diaz and Cabido 2001). Biodiversity-ecosystem functioning relationships could be more precisely studied with the use of functional diversity indexes that are based not only on species composition and abundances but also on their functional traits (Villéger et al. 2008). Functional traits characterise species morphology, physiology and behaviour, referring directly to species' role in the ecosystem (Litchman et al. 2013). Diversity analyses measured by trait-based indexes allow for improving the understanding of the relation between biodiversity and ecosystem functioning (Mouchet et al. 2010; Vaughn 2010; Hooper et al. 2012; Tilman et al. 2014).

One of the most crucial traits of the species is the body length, since it represents multiple correlated traits. Body length determines the amount of energy allocated in the specimen, its feeding rate, food particle (or prey) size, metabolism rate, etc. Another important trait is the species food source, characterising where the species uptakes energy from. The food source of all species in the community is also crucial for ecosystem functioning since it influences the food web structure and interactions between trophic groups (Litchman et al. 2013). Beside the food source, also the feeding type appears to be necessary both to species performance and the ecosystem functioning. Every feeding type (i.e., encountering food particles and capturing them) has its implications and trade-offs, and different strategies may be beneficial under different ecosystem conditions.

The above-mentioned traits of zooplankton may be used to define the functional trait space of the community, and functional diversity indexes are a tool used to describe the space. Linked and interpreted together, functional and biological diversity indexes provide more complementary information about the fitness of the ecosystem (Mouchet et al. 2010). 
Therefore, the aim of our study was to: (1) measure and compare the bio- and functional diversity of zooplankton; (2) find if bio- and functional diversity indexes correlate with each other; (3) examine the effect of short- and long-lasting cyanobacterial blooms and the effect of cyanobacterial biomass on the zooplankton community in small, shallow, eutrophic water bodies. We hypothesised that prolonged bloom events trigger changes by decreasing the bio- and functional diversity of freshwater zooplankton. We used functional diversity indexes as a support for classical biodiversity measures to study the effect of cyanobacterial bloom on the zooplankton communities. Serving as food for fish and many other organisms related to water habitats, planktonic animals are crucial for the functioning of aquatic ecosystems.

\section{Materials and methods}

\section{Study area}

The study was conducted in four water bodies in the area of Cracow (Southern Poland, Table 1), two of them are oxbow lakes of the Vistula River (Piekary and Tyniec), and two are artificial ponds (Podkamycze 1 and Podkamycze 2). The studied water bodies are described precisely in Kosiba et al. (2018). Cyanobacterial blooms occurred in all of the studied reservoirs. The following definition of 'bloom' was applied: "a marked visible discoloration of the water that is caused (predominantly) by cyanobacteria" (Huisman et al. 2018). An additional factor which we measured and used as a complementation of the aforementioned definition is chlorophyll $a$ concentration. According to Nebaeus (1984), chlorophyll $a$ concentration over $20 \mu \mathrm{g} \mathrm{L}^{-1}$ is treated as a bloom.

In the oxbow lakes, the bloom (visible discoloration of water and chlorophyll $a$ concentration higher than $20 \mu \mathrm{g} \mathrm{L}{ }^{-1}$ ) occurred from one up to 3 months (August-October)we define them as 'short-lasting blooms'. In ponds, the blooms were present for 5 months (June-October); we define them as 'long-lasting blooms'. Further microscopic analyses confirmed that the blooms were created by cyanobacteria.

\section{Sampling}

All samples were collected from a central (deepest) point of each water body, from May to October 2014, at a depth of $1 \mathrm{~m}$. Basic physico-chemical parameters (water temperature, conductivity, $\mathrm{pH}$, chlorophyll a, oxygen saturation), and depth were measured in situ with a YSI 6600 V2 Multiparameter Probe, and the water transparency with Secchi disc. Biological samples consisted of phytoplankton, protozooplankton (ciliates) and metazooplankton (rotifers, cladocerans, copepods). One set of samples consisted of physico-chemical and biological samples collected simultaneously. In total, 64 sets of samples were collected: 24 sets from water bodies with short-lasting blooms, and 40 sets from water bodies with long-lasting blooms. Samples for biological analysis were collected from a volume of $10 \mathrm{~L}$ of water (based on two $5 \mathrm{~L}$ replicates), concentrated with planktonic net (10 $\mu \mathrm{m}$ for phytoplankton and ciliates and $50 \mu \mathrm{m}$ for metazooplankton) and fixed (Lugol's solution for the phytoplankton and ciliates, and $4 \%$ formaldehyde for the metazooplankton). Qualitative and quantitative analyses of the biological samples were performed using a Nikon H550L light microscope under the magnification of $40-400 \times$ in chamber $(0.5 \mathrm{~mL}$ for the phytoplankton, $1 \mathrm{~mL}$ for the ciliates and $0.5 \mathrm{~mL}$ for the metazooplankton). The cyanobacteria 


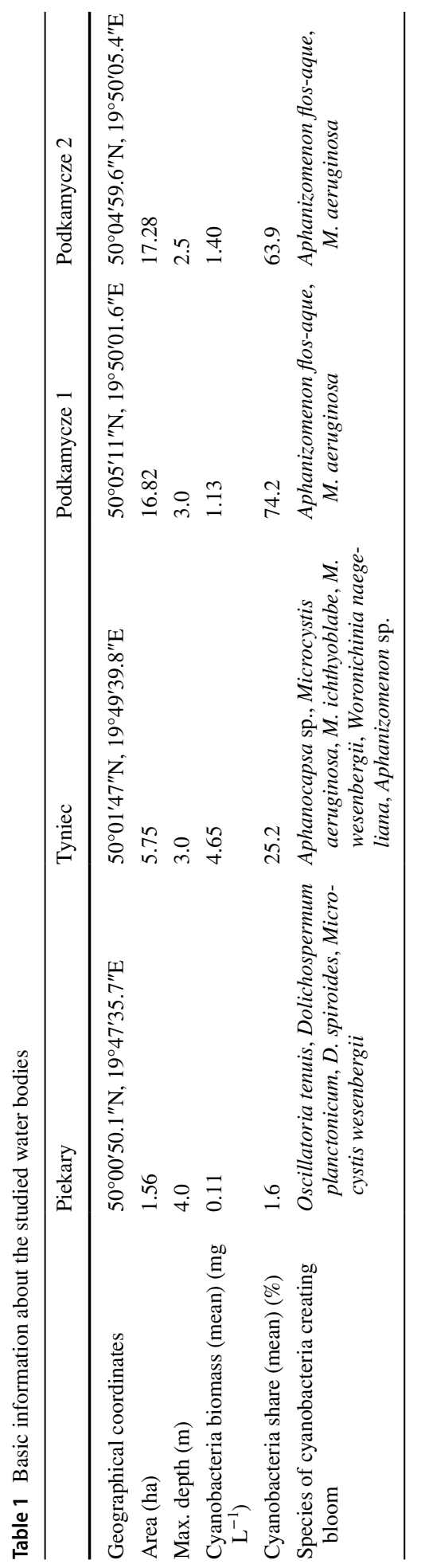


were identified with the use of keys (Komárek 2013; Komárek and Anagnostidis 1998, 2005) and their biomass was calculated as a biovolume by comparing the specimens with their geometrical shapes (Rott 1981). The zooplankton species were identified with the use of keys: Foissner and Berger (1996) and Foissner et al. (1999) for the protozooplankton and Ejsmont-Karabin et al. (2004) and Błędzki and Rybak (2016) for the metazooplankton. The density of the zooplankton was calculated based on multiple counts ( 3 subsamples for the protozooplankton and 5 subsamples for the metazooplankton), and recalculated to ind $\mathrm{L}^{-1}$.

\section{Statistical analyses, biodiversity and functional diversity indexes calculation}

Three biodiversity indexes were measured: species richness (SR), Simpson's Diversity Index (D) and Shannon's Diversity Index (H). Species richness (SR) was calculated as the number of species in the community. Simpson's and Shannon's indexes were calculated in R (R Core Team 2018) with the use of the 'vegan' package (Oksanen et al. 2013). We chose Shannon's (H) index due to its popularity as a general biodiversity measure and Simpson's (D) index as a measure of evenness (relative abundance) of species.

To describe the functional diversity of the studied zooplankton communities we used three functional diversity indexes: functional richness (Fric), functional evenness (Feve) and functional divergence (Fdiv). The Fric index describes the amount of trait space filled by the community, the Feve index describes how even is the abundance of the species distributed in the functional trait space, and the Fdiv index describes the degree of differentiation of functional traits among the community (Mason et al. 2005; Villéger et al. 2008).

The functional diversity indexes were calculated on the basis of species density and their functional traits. We chose three functional traits of each species: mean body length (BL), potential food source (FS) and feeding type (FT). They were calculated in R (R Core Team 2018) with the use of the 'FD' package (Laliberté and Legendre 2010; Laliberté et al. 2014).

BL was calculated as the mean body length of adult specimens of each species found in the zooplankton samples, and it is the only quantitative trait we used. FS was specified as a qualitative trait on the basis of available literature (see Appendix 1). We conducted a review of published works (with the use of Web of Science, Google Scholar and Scopus) in order to describe the FS trait value for each zooplankton species identified in the biological samples. Each species diet (i.e., potential food source) was described by one, up to three categories: bacterivorous and/or detitivores (B), algaevorous (A) and predator (P). FS is crucial for each species since it represents the trophic position and type of food consumed.

FT, as well as FS, was specified on the basis of the available literature as a qualitative trait. We qualified the species from our samples into four groups with final subcategories used in the analyses. The first group are suspension feeders with three subcategories: R-suspension feeders (Rsus-rotifers, with Malleate, Malleoramate and Incaudate Trophi); C-suspension feeders (Csus-copepods, both ambush-feeders and feeding-current feeders); and Cil-suspension feeders (Cilsus-ciliates, sieving food particles through ciliary structures) (Fenchel 1980; Kiørboe 2011; Ejsmont-Karabin et al. 2004). The second group are filter-feeders, divided into: Bosmina-type filtration (Bfil-where filtration takes place in a horizontal position); Chydorus-type filtration (Cfil—scrapping food particles from surfaces, characteristic for Chydorids); and Daphnia-type filtration (Dfil-where filtration takes place in a vertical position). In the Dfil subcategory we gathered animals which Barnett et al. (2007) treated as Daphnia-type and Sida-type filtration feeders given the similarity of these two filtration types (Barnett et al. 2007). The third group are piercers, 
consisting of rotifers with Virgate Trophi, which feed by sucking out the prey's cell content (de Oliveira Sodré et al. 2017). The fourth group are tactile feeders, specified only for one species - the predatory cladoceran Leptodora kindtii (Herzig and Auer, 1990).

In order to test the correlation among the biological and functional diversity indexes of the zooplankton community-principal component analysis (PCA) was performed, and to test the effect of cyanobacterial biomass, the effect of short- or long-lasting cyanobacterial bloom and the interaction of both factors on biological and functional diversity indexes of zooplankton community—generalised linear model (GLM) analysis was performed. Statistical analyses were conducted with R (R Core Team 2018) with the use of 'stats' (Generalized Linear Models-GLM; R Core Team 2018), 'FactoMineR' (Principal components analysis-PCA; Lê et al. 2008) and 'factoextra' (visualisation of the result of PCA analysis; Kassambara and Mundt 2017) packages.

\section{Results}

\section{Cyanobacterial blooms}

Blooms occurred in all of four studied water bodies, however they differed with duration and species forming bloom. In the oxbow lakes, the blooms were present from August to October, while in the ponds they were present from June to the end of October. In the Piekary oxbow lake, the bloom was formed by Oscillatoria tenuis, Dolichospermum planctonicum, D. spiroides and Microcystis wesenbergii. In the Tyniec oxbow lake, the bloom was formed by Aphanocapsa sp., Microcystis aeruginosa, M. ichthyoblabe, M. wesenbergii, Woronichinia naegeliana and Aphanizomenon sp. In the Podkamycze 1 and Podkamycze 2 water bodies, the blooms were formed by Aphanizomenon flos-aque and Microcystis aeruginosa. During the bloom, the biomass of cyanobacteria in the reservoirs with shortlasting blooms ranged from 0.04 to $12.83 \mathrm{mg} \mathrm{L}^{-1}$ (mean $3.24 \mathrm{mg} \mathrm{L}^{-1}$ ), and from 0.06 to $9.23 \mathrm{mg} \mathrm{L}^{-1}$ (mean $1.69 \mathrm{mg} \mathrm{L}^{-1}$ ) in reservoirs with long-lasting blooms.

\section{Biological and functional diversity of zooplankton}

In the studied reservoirs, 71 taxa of planktonic animals were found in total: 15 ciliates, 24 rotifers, 13 copepods and 19 cladocerans. Two juvenile stages of copepods were also found.

We found that zooplankton richness (SR) was higher (mean value for the entire season and particular months) in water bodies where short-lasting cyanobacterial blooms occurred. However, the variance and range of SR was higher in the artificial ponds with long-lasting cyanobacterial blooms (Fig. 1a, Table 2).

Simpson's Evenness Index (D, mean value) was only slightly lower in reservoirs with long-lasting blooms (Table 2), and also the mean values for particular months were lower in June, August, September and October in such reservoirs (Fig. 1b).

Shannon Diversity Index $(\mathrm{H})$ showed marginally higher mean value and variance in reservoirs with long-lasting cyanobacterial blooms (Table 2). Throughout the season we found mean values of $\mathrm{H}$ index slightly higher in water bodies where long-lasting cyanobacterial blooms occurred in June, September and October.

Fric mean value was higher in the water bodies with short-lasting blooms, however mean values of Feve and Fdiv were higher in the water bodies with long-lasting blooms 

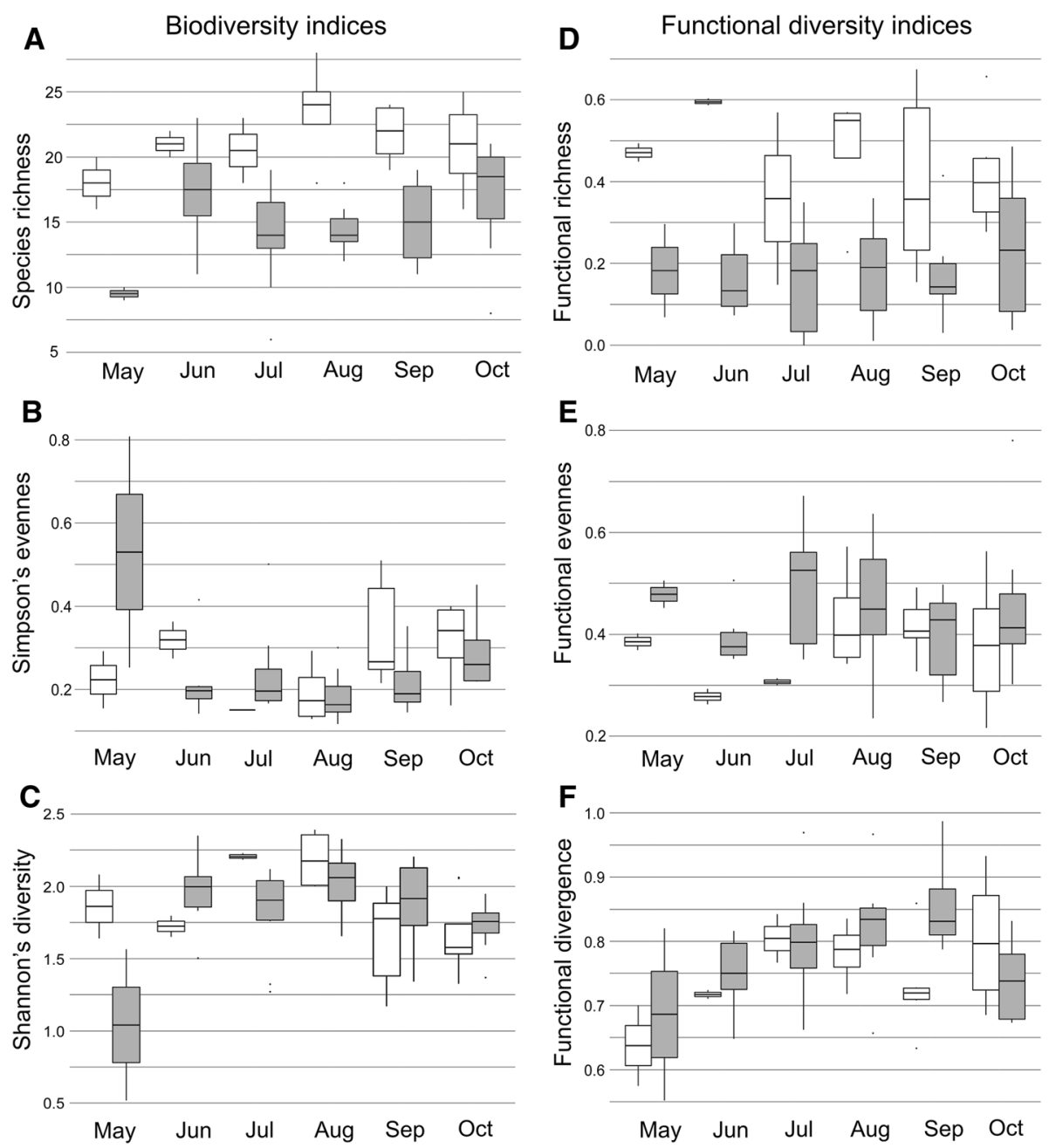

Fig. 1 Box plots for biological and functional diversity indexes during the season: a Species richness (SR); b Simpson's evenness (D); c Shannon's diversity (H); d functional richness (Fric); e functional evenness (Feve); f functional divergence (Fdiv). The horizontal lines represent median, the boxes represent 1 st and 3rd percentiles, the vertical lines represent range, and the points represent outliers. The white boxes represent values of each index for the water bodies where short-lasting blooms occurred, the grey boxes represent values for water bodies where long-lasting blooms occurred

(Table 2). The mean values of Fric in particular months were also higher in water bodies with short-lasting blooms in comparison to water bodies with long-lasting blooms (Fig. 1d). Feve and Fdiv showed higher mean values in particular months in water bodies with long-lasting blooms (Fig. 1e and f).

PCA analysis showed that SR was positively correlated to Fric. Both of these indexes were negatively correlated to the Feve index. Shannon's $(H)$ and Simpson's (D) indexes were correlated negatively to each other, and did not show correlation with other indexes. The analysis showed that the Fdiv index did not correlate to the other indexes (Fig. 2). 
Table 2 Values of indexes of diversity calculated for the zooplankton community in the reservoirs with short and long-lasting cyanobacterial bloom

\begin{tabular}{lrrrrrr}
\hline & \multicolumn{3}{l}{ Short-lasting blooms } & & & \multicolumn{2}{l}{ Long-lasting blooms } \\
\cline { 2 - 3 } \cline { 6 - 7 } \cline { 6 - 7 } & Range (mean) & & Variance & & Range (mean) & Variance \\
\hline Species richness (SR) & $16-28(21.29)$ & 9.17 & & $6-23(15.05)$ & 14.92 \\
Simpson evenness (D) & $0.129-0.51(0.279)$ & 0.012 & & $0.117-0.81(0.245)$ & 0.015 \\
Shannon diversity (H) & $1.171-2.391(1.811)$ & 0.112 & & $0.518-2.349(1.892)$ & 0.119 \\
Functional richness (Fric) & $0.148-0.674(0.433)$ & 0.026 & & $8.3 E-7-0.485(0.186)$ & 0.018 \\
Functional evenness (Feve) & $0.216-0.572(0.382)$ & 0.008 & & $0.236-0.781(0.448)$ & 0.013 \\
Functional divergence (Fdiv) & $0.575-0.933(0.760)$ & 0.007 & & $0.552-0.987(0.787)$ & 0.008 \\
\hline
\end{tabular}

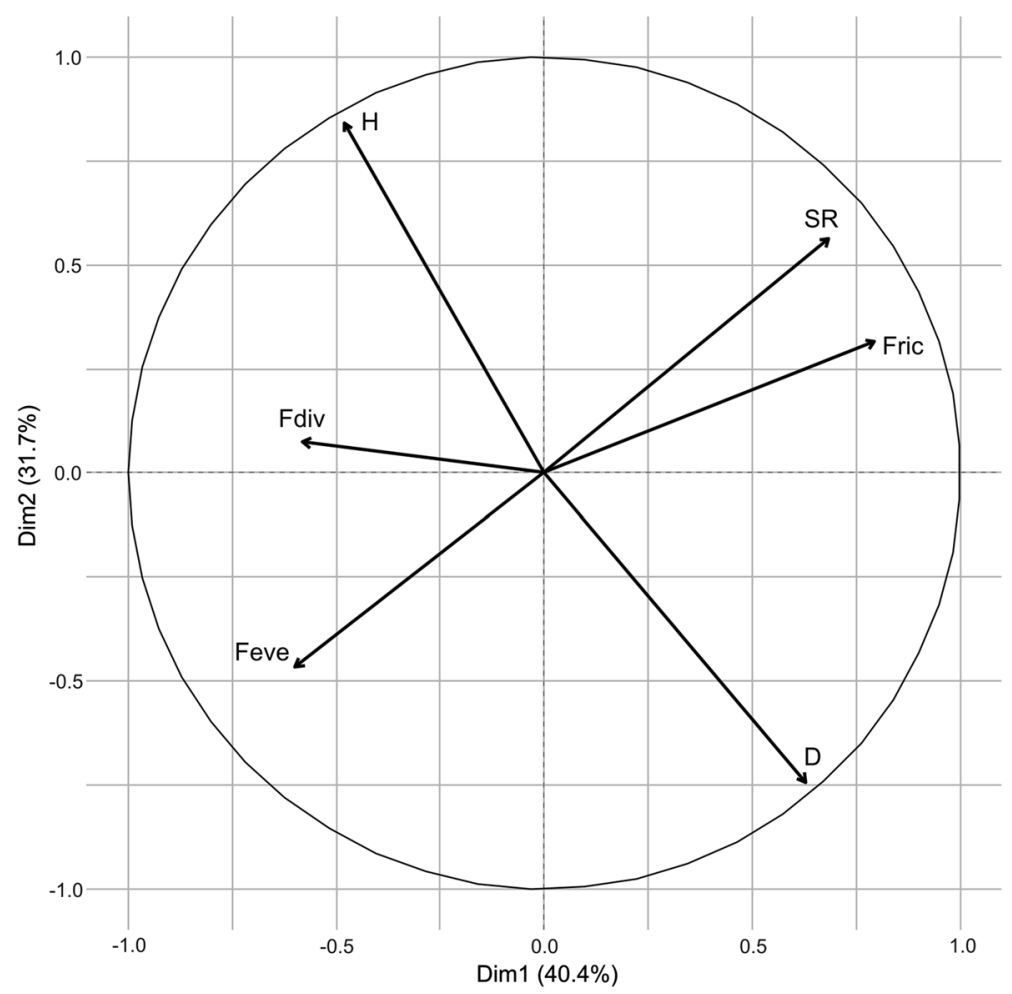

Fig. 2 PCA for biological and functional diversity indexes values in the studied reservoirs. The cumulative explained variation (for axis 1 and 2 ) is $72.12 \%$. SR species richness, $D$ Simpson's evenness, $H$ Shannon's diversity, Fric functional richness, Feve functional evenness, Fdiv functional divergence

GLM showed that SR in ponds with long-lasting cyanobacterial blooms was significantly lower $(\mathrm{p}<0.001)$ compared to SR in ponds with short-lasting blooms (Tables 2 and 3). However, the analysis did not show significant differences for both types of ecosystems, neither for the D nor for the $\mathrm{H}$ indexes (Tables 2 and 3). For the functional diversity indexes, GLM showed: the Fric index significantly lower in ponds 
Table 3 The results of GLM analysis conducted for biodiversity and functional diversity indexes against the length of cyanobacterial bloom (factor), biomass of cyanobacteria and the interaction of cyanobacteria biomass and length of bloom

\begin{tabular}{|c|c|c|c|c|}
\hline Predictor & Estimate & Std. error & $\mathrm{T}$ & $\mathrm{p}$ \\
\hline \multicolumn{5}{|l|}{ Species richness (SR) } \\
\hline Short-lasting bloom (intercept) & 20.676 & 0.874 & 23.671 & $<0.001$ \\
\hline Cyanobacteria biomass & 0.240 & 0.201 & 1.192 & 0.238 \\
\hline Long-lasting bloom & -4.871 & 1.082 & -4.503 & $<0.001$ \\
\hline Cyano $\times$ long-lasting bloom & -0.837 & 0.331 & -2.532 & $<0.05$ \\
\hline \multicolumn{5}{|l|}{ Simpson's evenness (D) } \\
\hline Short-lasting bloom (intercept) & 0.276 & 0.031 & 8.955 & $<0.001$ \\
\hline Cyanobacteria biomass & 0.001 & 0.007 & -0.186 & 0.853 \\
\hline Long-lasting bloom & -0.026 & 0.038 & 0.679 & 0.499 \\
\hline Cyano $\times$ long-lasting bloom & -0.005 & 0.012 & 0.414 & 0.681 \\
\hline \multicolumn{5}{|l|}{ Shannon diversity $(\mathrm{H})$} \\
\hline Short-lasting bloom (intercept) & 1.797 & 0.088 & 20.475 & $<0.001$ \\
\hline Cyanobacteria biomass & 0.005 & 0.020 & 0.264 & 0.793 \\
\hline Long-lasting bloom & 0.047 & 0.109 & 0.428 & 0.670 \\
\hline Cyano $\times$ long-lasting bloom & -0.017 & 0.033 & -0.508 & 0.614 \\
\hline \multicolumn{5}{|l|}{ Functional richness (Fric) } \\
\hline Short-lasting bloom (intercept) & 0.494 & 0.034 & 14.692 & $<0.001$ \\
\hline Cyanobacteria biomass & -0.024 & 0.008 & -3.067 & $<0.01$ \\
\hline Long-lasting bloom & -0.284 & 0.042 & -6.814 & $<0.001$ \\
\hline Cyano $\times$ long-lasting bloom & 0.004 & 0.013 & 0.323 & 0.748 \\
\hline \multicolumn{5}{|l|}{ Functional evenness (Feve) } \\
\hline Short-lasting bloom (intercept) & 0.353 & 0.026 & 13.438 & $<0.001$ \\
\hline Cyanobacteria biomass & 0.011 & 0.006 & 1.854 & 0.069 \\
\hline Long-lasting bloom & 0.090 & 0.032 & 2.767 & $<0.01$ \\
\hline Cyano $\times$ long-lasting bloom & -0.007 & 0.010 & -0.722 & 0.473 \\
\hline \multicolumn{5}{|l|}{ Functional divergence (Fdiv) } \\
\hline Short-lasting bloom (intercept) & 0.743 & 0.022 & 34.356 & $<0.001$ \\
\hline Cyanobacteria biomass & 0.007 & 0.005 & 1.355 & 0.181 \\
\hline Long-lasting bloom & 0.029 & 0.027 & 1.068 & 0.290 \\
\hline Cyano $\times$ long-lasting bloom & 0.006 & 0.008 & 0.685 & 0.496 \\
\hline
\end{tabular}

The $\mathrm{p}$ values in bold are statistically significant

with long-lasting cyanobacterial blooms $(\mathrm{p}<0.001)$, and the Feve index significantly higher in ponds with long-lasting cyanobacterial blooms $(\mathrm{p}<0.01)$ in comparison to the waters with short-lasting blooms. No statistical differences were showed between the Fdiv index of both types of ecosystems (Tables 2 and 3).

GLM showed the biomass of cyanobacteria affected (Table 3): SR in waters with long-lasting blooms $(p<0.05)$, Fric in waters with short-lasting blooms $(p<0.001)$ and Feve in waters with long-lasting blooms $(\mathrm{p}<0.01)$. 


\section{Discussion}

The biodiversity of aquatic ecosystems has been intensively studied over the last decades (Fryer 1980; Gee et al. 1997; Dudgeon et al. 2006). Traditional biodiversity indexes have come in for criticism because they treat all species and individuals equally (Mouchet et al. 2010). This is the reason why a new approach-measuring diversity using functional traits of species-has been proposed (Tilman 2001; Villéger et al. 2008). The range of species functional traits (functional trait space) characterise the species roles in the ecosystem processes, which is useful for studying communities of numerous and diverse species (Loreau et al. 2001; Hooper et al. 2005). Such a community is zooplankton, consisting of crustaceans (cladocerans and copepods), rotifers and ciliates, which differ in many aspects (body size and morphology, feeding behaviour etc.). The choice of traits used in the study became limited since each of traits had to be well described for every species. Petchey and Gaston (2006) defined the choice of functional traits as a critical for studying functional diversity. The traits have to refer to the most important features of the species which are responsible for their impact on the food web and ecosystem processes. Therefore, the possible limitation of the study is joining calanoid (feeding-current feeders) and cyclopoid (ambush-feeding feeders) copepods under the single Csus feeding trait. However, the aim of the study was not to distinguish which traits of zooplankton are associated with the cyanobacterial bloom, but to test how the bloom modify the trait space of the community. Here, the Csus trait represents not only the mechanism of food uptake but also the ability of selective feeding.

Among freshwater food webs, interactions between trophic levels are often more relevant than interactions between organisms occupying the same trophic level (Woodward 2009). Therefore, the zooplankton community may be limited by both bottom-up (food availability) and top-down (fish predation) effects (Gliwicz 2002). The observed effects of predatory pressure of fish are narrowing the size spectrum of the zooplankton community, causing the elimination of large bodied crustaceans, and switching the community towards rotifer domination (Reissig et al. 2006). The study we carried out did not consider detailed fish abundance (predatory pressure). Nevertheless, on the basis of the consultations with authorities of the Polish Angling Association and owner of the ponds, we can estimate the fish pressure on a similar level in all of the water bodies, so potential differences in top-down control may be negligible.

Studying biodiversity-ecosystem functioning relations are important for predicting how multispecies systems respond to stress factors. In this study, we used classical and trait-based methods to learn how the cyanobacterial bloom affect the bio- and functional diversity of zooplankton.

\section{What did the traditional indexes show?}

Using traditional indexes of diversity we found that only species richness (SR) showed the differences between ecosystems with short and long-lasting blooms. In ecosystems with short-lasting blooms, we found a higher number of species compared to those with long-lasting blooms. This might support the conclusions of Ger et al. (2014) that more intensive and prolonged cyanobacterial blooms triggers selection of better adapted species and, as a consequence, in such waters the number of species decreases. 
Shannon's (H) and Simpson's (D) indexes showed a similar distribution of values in both types of water ecosystems. However, a broader range and a slightly larger variation of indexes in ponds with long-lasting blooms indicate higher fluctuation throughout the season. The comparable mean values of the indexes in both types of water bodies may be an effect of changes of zooplankton composition without loss of biodiversity (Bouvy et al. 2001).

\section{What did the functional diversity indexes show?}

Functional richness (Fric) values were lower in the water bodies with long-lasting cyanobacterial blooms during the entire season. This result indicates the limited ecological function of the community (Ger et al. 2014), which the authors explain as a selection of betteradapted species by prolonged blooms. According to Mason et al. (2005), lower Fric may suggest, however, that some of the resources in the environment are available, but that they are unused, which leads to the presence of niche space gaps. Since aquatic habitats are susceptible to invasions, these gaps may represent an opportunity for invaders (Lozon and MacIsaac 1997; Dukes 2001; Mason et al. 2005). Additionally, we found that functional evenness (Feve) of the zooplankton community was higher in the water bodies with longlasting cyanobacterial blooms. According to Woodward (2009), evenness is the exception in nature (among freshwater ecosystems) and dominance is the rule. The fact that a longlasting bloom forces more even distribution of traits in the zooplankton community (also understood as a lesser domination of one species in the community; Villéger et al. 2008) suggests that prolonged cyanobacteria domination is a driver of the weakening of natural processes. Our results corroborate with the study of Josué et al. (2018), who found cyanobacterial dominance reducing Functional dispersion of the zooplankton community (leading to the occurrence of species possessing similar functional traits) which may limit the zooplankton role in an ecosystem.

Lower Fric and Feve in the water bodies with long-lasting blooms suggest that the events force changes among available niches. Since a zooplankton community consists of species diversified in many aspects, there is a clear resource niche differentiation among every habitat they dwell in (Wilson 1990). Resources may become limited during the cyanobacterial bloom (Havens 2008), affecting also the differentiation of the niches. We did not find significant difference in Fdiv (functional divergence) values in water bodies with different types of bloom, which indicates that the length of the bloom did not affect the differentiation of the niches. We explain this phenomenon as the ability of the species in the community to adapt to the circumstances of resources shortage by switching to an alternative food source.

\section{Do the bio- and functional diversity indexes correlate?}

In order to check if traditional biodiversity indexes and functional diversity indexes are complementary, we used PCA analysis. A positive correlation of species richness (SR) and functional richness (Fric) showed that both of them are related to each other. The positive correlation between SR and Fric index may be implied by construction of the Fric index (Mason et al. 2005). Both of these indexes showed a negative correlation to the Feve index, suggesting that higher species richness and functional richness (Fric) were connected to domination of the community by a particular species. 
Negative correlation between the Shannon (H) and Simpson (D) indexes was found, but they did not correlate with any other indexes. It is clear that these indexes provide information on how the community is diversified ( $\mathrm{H}$ index), and how evenly the species are distributed (D index) among the community. Lack of correlation with functional evenness (Feve) and functional divergence (Fdiv) clearly showed that trait-based indexes provide some other information than classical biodiversity measures. They describe the functional trait space of the community, which is possible due to the incorporation of species functional traits into the indexes (Villéger et al. 2008). Furthermore, no correlation of functional divergence (Fdiv) with other indexes is explained by the fact that traits distribution in the community is not dependent on species richness and any other aspects of traditional understanding of diversity.

\section{The effect of cyanobacterial blooms on bio- and functional diversity}

During the bloom, cyanobacteria dominate freshwater ecosystems, developing a large amount of biomass which is poorly available for grazers as a food. This may promote the development of some more selective species (ciliates, rotifers, cladocerans), effectively feeding on an alternative food source such as bacteria (Zöllner et al. 2003; Arndt 1993; Brendelberger 1991; Geller and Müller 1981). Such interactions in the microbial food web induce modifications of the zooplankton composition and, as a consequence, a set of functional traits of the community. Thanks to the use of functional diversity measures, our study shows that different aspects of functional diversity were affected by cyanobacterial bloom.

The GLM showed that the species richness (SR) was not affected by increasing cyanobacterial biomass in water bodies with short-lasting blooms, but it was affected in water bodies with long-lasting cyanobacterial blooms. Short-lasting blooms are natural phenomena, and the increase of cyanobacterial biomass in natural cycles may not trigger rapid changes of zooplankton biodiversity. On the other hand, the lack of changes in SR might be explained as replacement of the species i.e., the decline of more vulnerable and the development of better adapted species. However, the negative effect of cyanobacterial biomass on Fric was found, but only in water bodies with short-lasting blooms. Such an effect represents the limitation of trait values, which is an effect of the inadequacy of cyanobacteria as a food source (Bednarska et al. 2014). We explain no effect of cyanobacterial biomass on Fric in reservoirs with long-lasting blooms as an adaptation of the community of these water bodies for prolonged bloom circumstances. The differences in the effects of the interaction of long-lasting bloom and cyanobacterial biomass (negative on SR and no effect on Fric) suggests that despite the disappearance of some species, the trait space remained unchanged. It can be explained as a fact of the existence of the community assembled of species adapted to circumstances of prolonged blooms. Furthermore, the increase of cyanobacterial biomass did not significantly affect the values of classically-used biodiversity indexes (Simpson's D and Shannon's H). Such a result is contrary to what we expected due to the fact that cyanobacterial blooms may be harmful for the entire food web (Paerl et al. 2001; Hansson et al. 2007). Nevertheless, recently there is increasing number of reports demonstrating that cyanobacteria-zooplankton interactions are more complicated, and genetic changes of both cyanobacteria and planktonic animals might change the mutual response (Wilk-Woźniak 2019).

We found cyanobacterial biomass effect on Feve on the border of significance in water bodies with short-lasting cyanobacterial blooms. This indicates that in some circumstances 
cyanobacterial biomass could modify the Feve towards more even distribution of the species in the functional trait space. Our results coincide with the study of Massicotte et al. (2014), who found a negative correlation of chlorophyll $a$ concentration and Feve of the zooplankton community, which may be interpreted as a bottom-up effect of phytoplankton assemblage. No effect of cyanobacterial biomass on Fdiv (in both types of reservoirs) suggests that their unsuitability as a food source does not enhance species traits distribution in the community. During the season we noticed the highest values of Fdiv from July to September in reservoirs with prolonged blooms, and in October in reservoirs where short-lasting blooms occurred. The highest values of Fdiv were associated with the highest percentage share of cyanobacteria in total phytoplankton biomass. These observations suggest that cyanobacteria may cause an enhancement of the traits towards extreme values, however lack of statistical evidence does not confirm that conclusion. Lack of significant effects of cyanobacterial biomass on both Feve and Fdiv indexes might be explained by the diversity of cyanobacteria. The size, shape (filamentous and chroococcal) and other functional traits of cyanobacterial cells provide different niche spaces for zooplankton. Including this issue into the analyses may reveal numerous associations of zooplankton and cyanobacteria traits which will be helpful in an understanding of the interactions of the aforementioned groups.

\section{Conclusions}

Functional diversity indexes are a reliable supplementation for traditional biodiversity indexes. They provide a set of additional information about the functional trait space of studied community, and allow for tracking changes which are undetectable by classic biodiversity measures. Simpson's D and Shannon's H indexes showed no loss of biodiversity of zooplankton caused by an increase of cyanobacterial biomass and duration of the bloom. Use of functional diversity measures allowed for concluding that the aforementioned factors involved changes among the community, however the dimension of the changes was not the classical biodiversity, but the functional trait space of the community. A decrease of functional richness (Fric) and an increase of functional evenness (Feve) caused by long-lasting bloom show that massive cyanobacteria development are responsible for the limitation of the role of the zooplankton community. A functional approach (i.e., measuring the functional trait space and its features) revealed that proliferated blooms may affect resource use by the zooplankton community and weaken the natural ecological processes and functioning of freshwater ecosystems.

Acknowledgements We thank Edward Walusiak Ph.D. for his assistance during the field work. This study was supported by the Institute of Nature Conservation, Polish Academy of Sciences, through its statutory fund and a grant for young scientists and Ph.D. candidates.

Open Access This article is distributed under the terms of the Creative Commons Attribution 4.0 International License (http://creativecommons.org/licenses/by/4.0/), which permits unrestricted use, distribution, and reproduction in any medium, provided you give appropriate credit to the original author(s) and the source, provide a link to the Creative Commons license, and indicate if changes were made.

\section{Appendix 1}

See Table 4. 


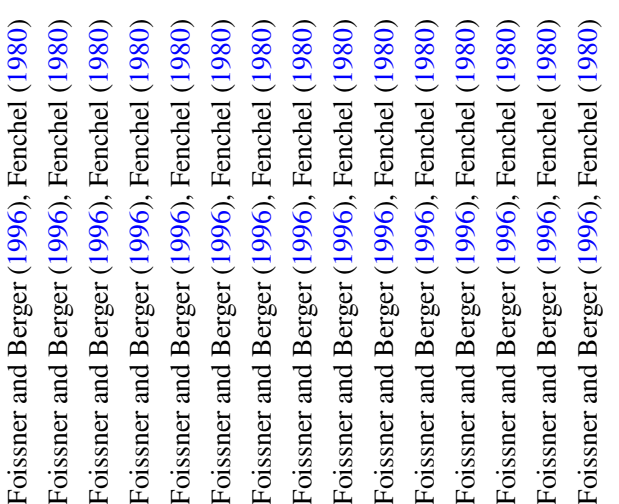

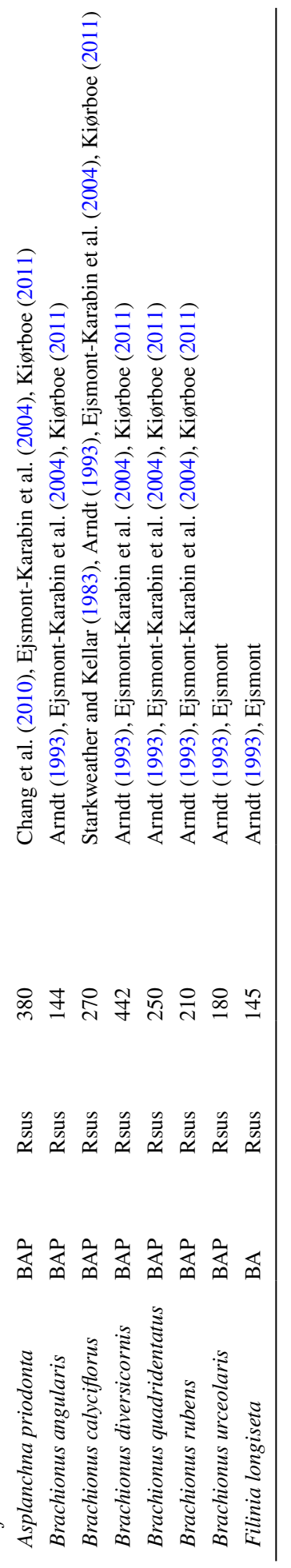

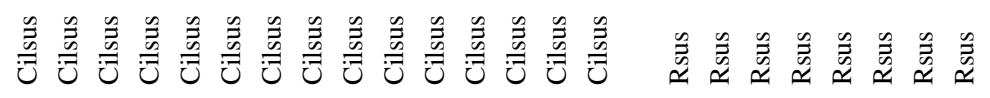

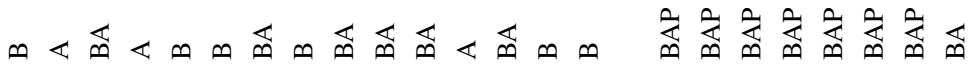

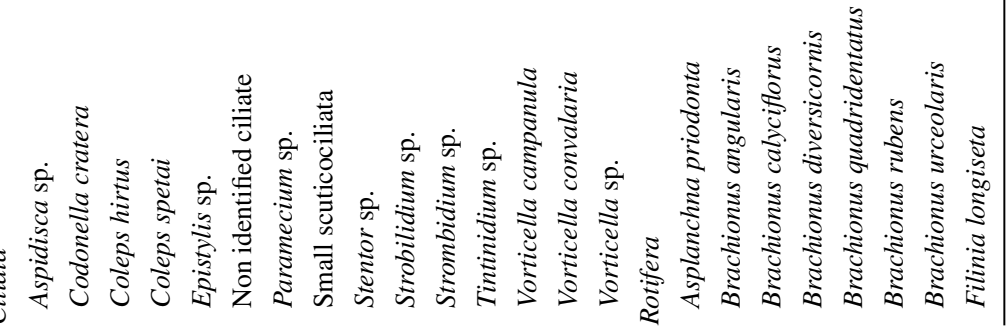




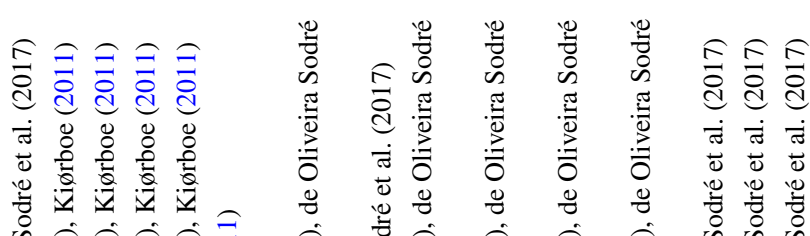

क

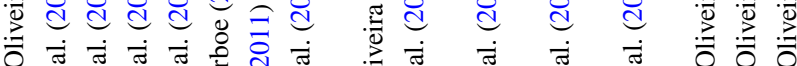

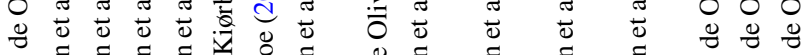

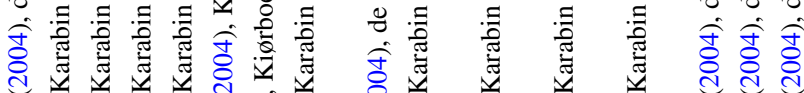

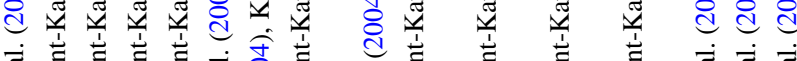

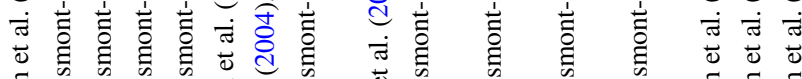

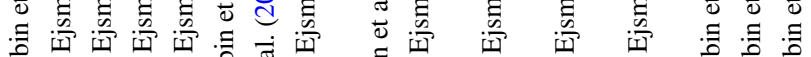

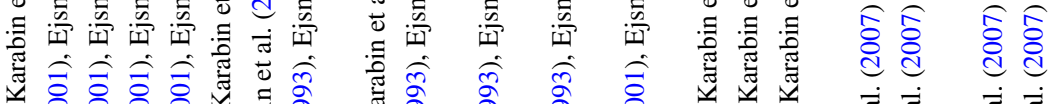

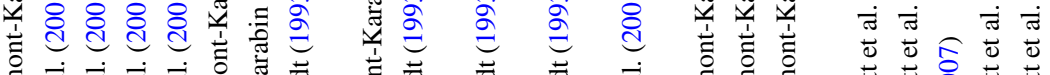

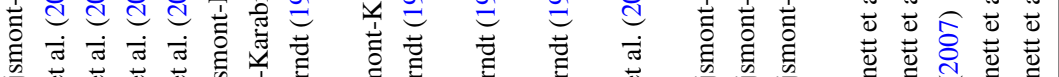

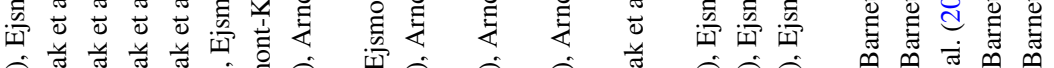

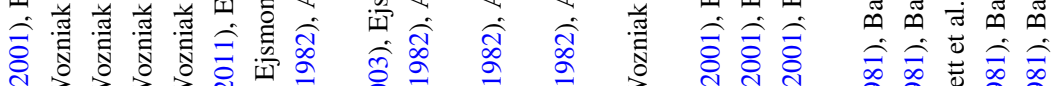

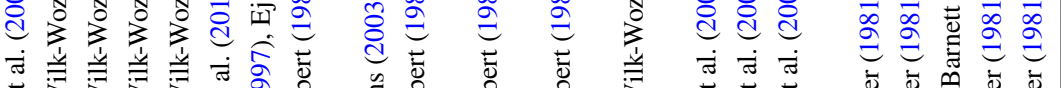

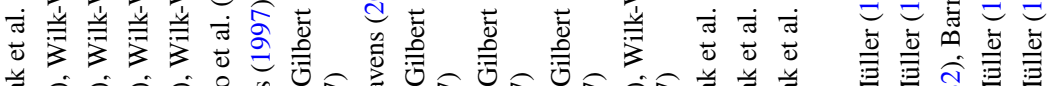

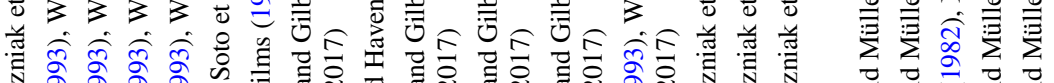

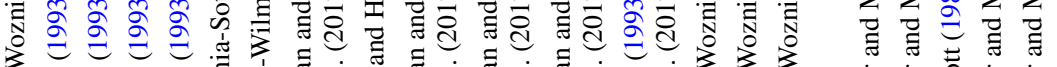

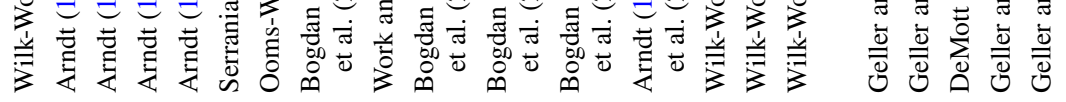

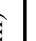

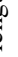

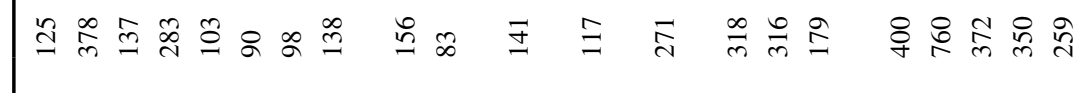

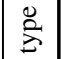

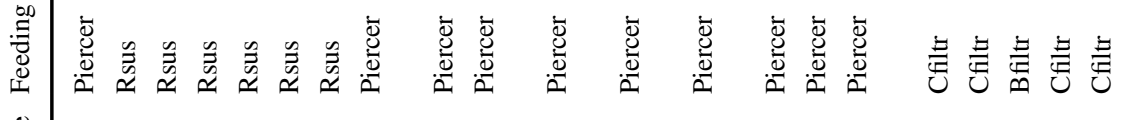
(1)

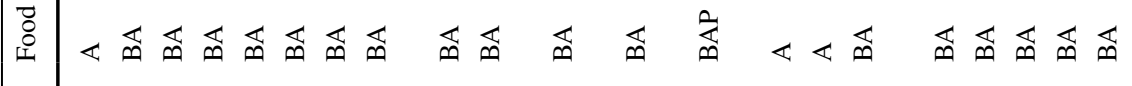

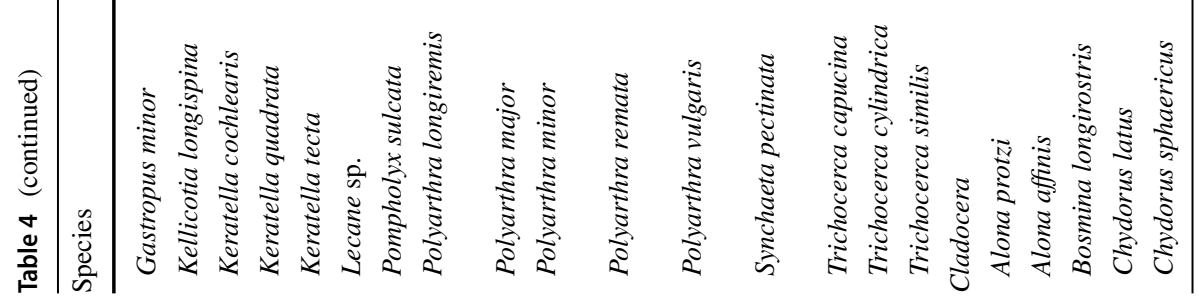




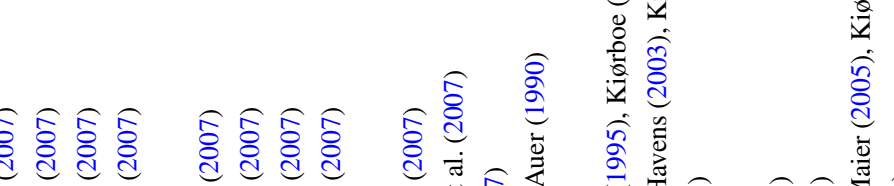

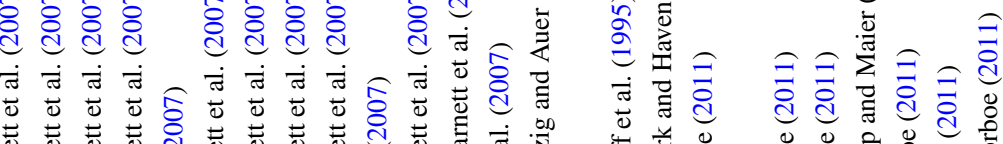

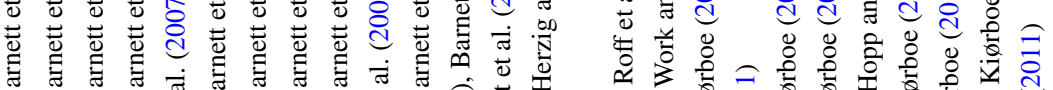

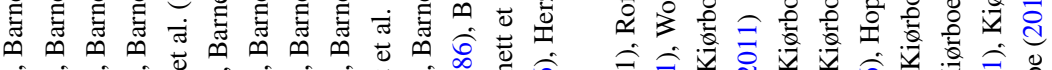

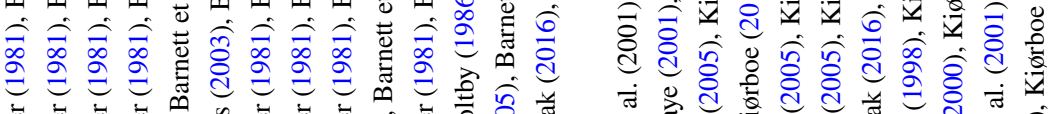

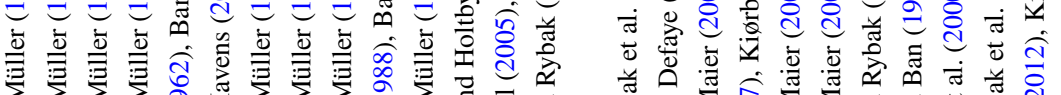

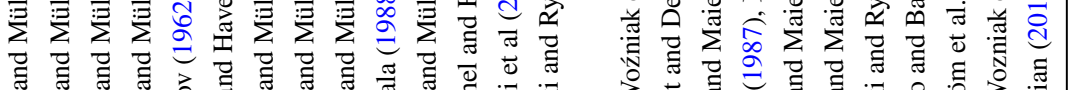

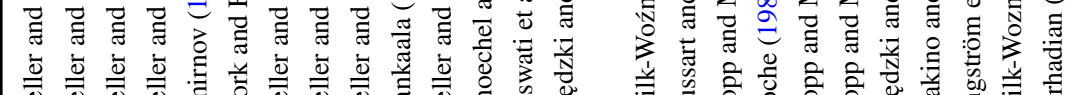

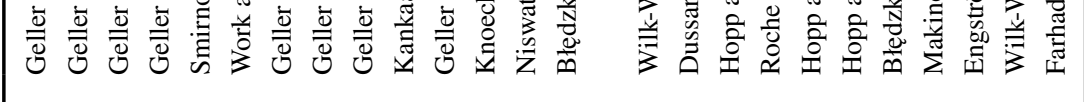

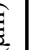

m ङั.

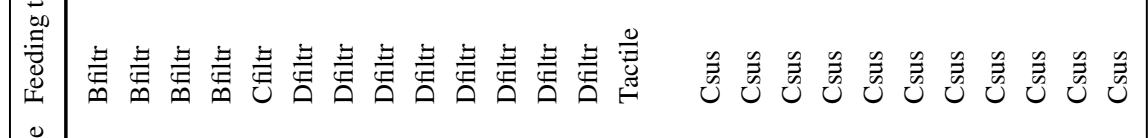

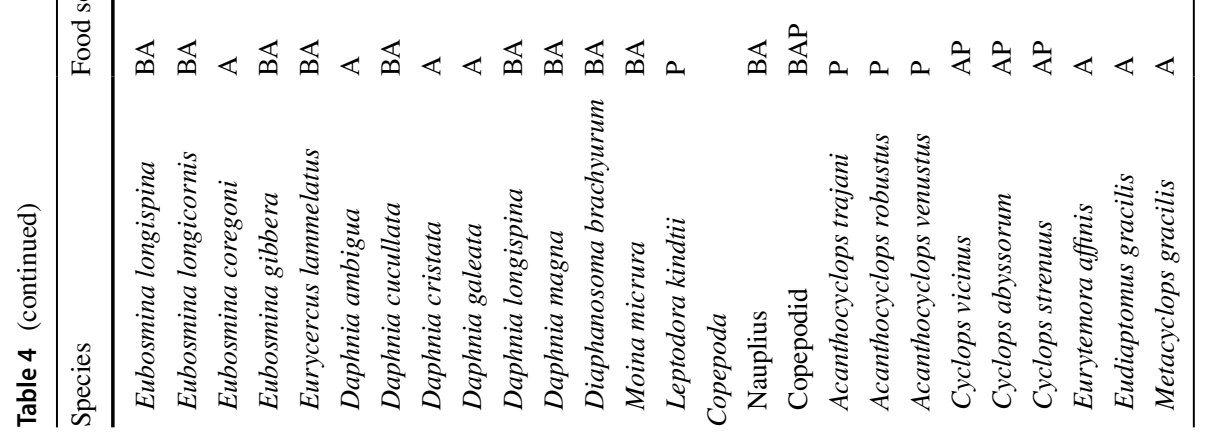




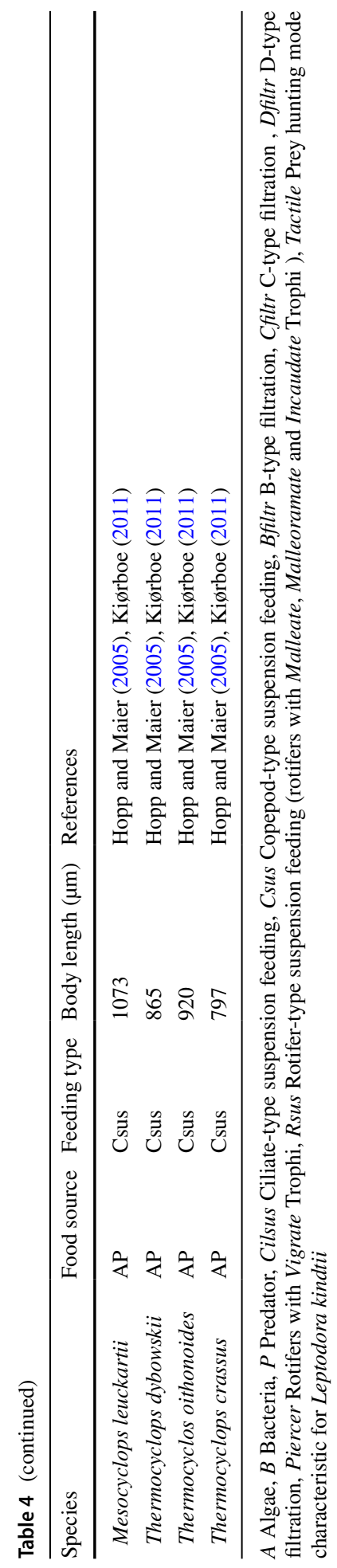




\section{References}

Arndt H (1993) Rotifers as predators on components of the microbial web (bacteria, heterotrophic flagellates, ciliates)—a review. In: Gilbert JJ, Lubzens E, Miracle MR (eds) Rotifer symposium VI. Developments in hydrobiology, vol 83. Springer, Dordrecht

Barnett AJ, Finlay K, Beisner BE (2007) Functional diversity of crustacean zooplankton communities: towards a trait-based classification. Freshw Biol 52(5):796-813

Barnosky AD, Matzke N, Tomiya S, Wogan GO, Swartz B, Quental TB, Marshall C, McGuire JL, Lindsey EL, Maguire KC, Mersey B (2011) Has the Earth's sixth mass extinction already arrived? Nature 471(7336):51

Bednarska A, Pietrzak B, Pijanowska J (2014) Effect of poor manageability and low nutritional value of cyanobacteria on Daphnia magna life history performance. J Plankton Res 36(3):838-847

Błędzki LA, Rybak JI (2016) Freshwater crustacean zooplankton of Europe: Cladocera \& Copepoda (Calanoida, Cyclopoida) key to species identification, with notes on ecology, distribution, methods and introduction to data analysis. Springer, New York

Bogdan KG, Gilbert JJ (1982) Seasonal patterns of feeding by natural populations of Keratella, Polyarthra, and Bosmina: clearance rates, selectivities, and contributions to community grazing. Limnol Oceanogr 27(5):918-934

Bouvy M, Pagano M, Troussellier M (2001) Effects of a cyanobacterial bloom (Cylindrospermopsis raciborskii) on bacteria and zooplankton communities in Ingazeira reservoir (northeast Brazil). Aquat Microb Ecol 25(3):215-227

Brendelberger H (1991) Filter mesh size of cladocerans predicts retention efficiency for bacteria. Limnol Oceanogr 36(5):884-894

Chang KH, Hideyuki DOI, Nishibe Y, Nakano SI (2010) Feeding habits of omnivorous Asplanchna: comparison of diet composition among Asplanchna herricki, A. priodonta and A. girodi in pond ecosystems. J Limnol 69(2):209-216

Crutzen PJ (2006) The "anthropocene". In: Ehlers E, Krafft T (eds) Earth system science in the anthropocene. Springer, Berlin, pp 13-18

de Oliveira Sodré E, Figueiredo-Barros MP, Roland F, de Assis Esteves F, Bozelli RL (2017) Complimentary biodiversity measures applied to zooplankton in a recovering floodplain lake. Fund Appl Limnol/ Arch Hydrobiol 190(4):279-298

DeMott WR (1982) Feeding selectivities and relative ingestion rates of Daphnia and Bosmina. Limnol Oceanogr 27(3):518-527

Diaz S, Cabido M (2001) Vive la difference: plant functional diversity matters to ecosystem processes. Trends Ecol Evol 16(11):646-655

Dudgeon D, Arthington AH, Gessner MO, Kawabata ZI, Knowler DJ, Lévêque C, Naiman RJ, Prieur-Richard AH, Soto D, Stiassny ML, Sullivan CA (2006) Freshwater biodiversity: importance, threats, status and conservation challenges. Biol Rev 81(2):163-182

Dukes JS (2001) Biodiversity and invasibility in grassland microcosms. Oecologia 126:563-568

Dussart BH, Defaye D (2001) Introduction to the Copepoda. Guide to the identification of the microinvertebrates of the continental waters of the world, No. 16

Ejsmont-Karabin J, Radwan S, Bielańska-Grajner I (2004) Rotifers. Monogononta-atlas of species. Polish freshwater fauna. University of Łódź, Łódź, pp 77-447

Engström J, Koski M, Viitasalo M, Reinikainen M, Repka S, Sivonen K (2000) Feeding interactions of the copepods Eurytemora affinis and Acartia bifilosa with the cyanobacteria Nodularia sp. J Plankton Res 22(7):1403-1409

Farhadian O (2012) Culture of cyclopoid copepod Metacyclops gracilis fed on Scenedesmus quadricauda at different oxygen concentrations. Iran Sci Fish J 1(78):123-132

Fenchel T (1980) Suspension feeding in ciliated protozoa: structure and function of feeding organelles. Arch Protistenkd 123(3):239-260

Foissner W, Berger H (1996) A user-friendly guide to the ciliates (Protozoa, Ciliophora) commonly used by hydrobiologists as bioindicators in rivers, lakes, and waste waters, with notes on their ecology. Freshw Biol 35(2):375-482

Foissner W, Berger H, Schaumburg J (1999) Identification and ecology of limnetic plankton ciliates. Informationsberichte des Bayer. Landesamtes für Wasserwirtschaft, München

Fryer G (1980) Acidity and species diversity in freshwater crustacean faunas. Freshw Biol 10(1):41-45

Gee JH, Smith BD, Lee KM, Griffiths SW (1997) The ecological basis of freshwater pond management for biodiversity. Aquat Conserv 7(2):91-104

Geller W, Müller H (1981) The filtration apparatus of Cladocera: filter mesh-sizes and their implications on food selectivity. Oecologia 49(3):316-321 
Ger KA, Hansson LA, Lürling M (2014) Understanding cyanobacteria-zooplankton interactions in a more eutrophic world. Freshw Biol 59(9):1783-1798

Ger KA, Urrutia-Cordero P, Frost PC, Hansson LA, Sarnelle O, Wilson AE, Lürling M (2016) The interaction between cyanobacteria and zooplankton in a more eutrophic world. Harmful Algae $54: 128-144$

Gliwicz ZM (2002) On the different nature of top-down and bottom-up effects in pelagic food webs. Freshw Biol 47(12):2296-2312

Hansson LA, Gustafsson S, Rengefors K, Bomark L (2007) Cyanobacterial chemical warfare affects zooplankton community composition. Freshw Biol 52(7):1290-1301

Havens KE (2008) Cyanobacteria blooms: effects on aquatic ecosystems. In: Hundell HK (ed) Cyanobacterial harmful algal blooms: state of the science and research needs. Springer, New York, pp $733-747$

Herzig A, Auer B (1990) The feeding behaviour of Leptodora kindti and its impact on the zooplankton community of Neusiedler See (Austria). Hydrobiologia 198(1):107-117

Hooper DU, Chapin FS, Ewel JJ, Hector A, Inchausti P, Lavorel S et al (2005) Effects of biodiversity on ecosystem functioning: a consensus of current knowledge. Ecol Monogr 75(1):3-35

Hooper DU, Adair EC, Cardinale BJ, Byrnes JE, Hungate BA, Matulich KL et al (2012) A global synthesis reveals biodiversity loss as a major driver of ecosystem change. Nature 486(7401):105

Hopp U, Maier G (2005) Implication of the feeding limb morphology for herbivorous feeding in some freshwater cyclopoid copepods. Freshw Biol 50(5):742-747

Huisman J, Codd GA, Paerl HW, Ibelings BW, Verspagen JM, Visser PM (2018) Cyanobacterial blooms. Nat Rev Microbiol 16(8):471-483

Josué II, Cardoso SJ, Miranda M, Mucci M, Ger KA, Roland F, Marinho MM (2018) Cyanobacteria dominance drives zooplankton functional dispersion. Hydrobiologia 831:149-161

Kankaala P (1988) The relative importance of algae and bacteria as food for Daphnia longispina (Cladocera) in a polyhumic lake. Freshw Biol 19(3):285-296

Kassambara A, Mundt F (2017) Factoextra: extract and visualize the results of multivariate data analyses. R package version 1.0. 4. 2017

Kiørboe T (2011) How zooplankton feed: mechanisms, traits and trade-offs. Biol Rev 86(2):311-339

Knoechel R, Holtby LB (1986) Cladoceran filtering rate: body length relationships for bacterial and large algal particles. Limnol Oceanogr 31(1):195-199

Komárek J (2013) Süßwasserflora von Mitteleuropa, Bd. 19/3: Cyanoprokaryota. 3. Teil/3rd part: Heterocytous Genera. In: Büdel B, Gärtner G, Krienitz L, Schagerl M, von Gegründet PA (eds) Süßwasserflora von Mitteleuropa. Spektrum Academischer Verlag, Heidelberg

Komárek J, Anagnostidis K (1998) Cyanoprokaryota. 1. Chroococcales. Süsswasserflora von Mitteleuropa. Bd. 19(1):548S

Komárek J, Anagnostidis K (2005) Cyanoprokaryota 2. Teil: Oscillatoriales. Süsswasserflora von Mitteleuropa $19 / 2$

Kosiba J, Krztoń W, Wilk-Woźniak E (2018) Effect of microcystins on proto-and metazooplankton is more evident in artificial than in natural waterbodies. Microb Ecol 75(2):293-302

Laliberté E, Legendre P (2010) A distance-based framework for measuring functional diversity from multiple traits. Ecology 91:299-305

Laliberté E, Legendre P, Shipley B (2014) FD: measuring functional diversity from multiple traits, and other tools for functional ecology. $\mathrm{R}$ package version 1.0-12

Lê S, Josse J, Husson F (2008) FactoMineR: an R package for multivariate analysis. J Stat Softw 25(1):1-18

Litchman E, Ohman MD, Kiørboe T (2013) Trait-based approaches to zooplankton communities. J Plankton Res 35(3):473-484

Loreau M, Naeem S, Inchausti P, Bengtsson J, Grime JP, Hector A, Hooper DU, Huston MA, Raffaelli D, Schmid B, Tilman D, Wardle DA (2001) Biodiversity and ecosystem functioning: current knowledge and future challenges. Science 294(5543):804-808

Lozon JD, MacIsaac HJ (1997) Biological invasions: are they dependent on disturbance? Environ Rev 5(2):131-144

Makino W, Ban S (1998) Diel changes in vertical overlap between Cyclops strenuus (Copepoda; Cyclopoida) and its prey in oligotrophic Lake Toya, Hokkaido, Japan. J Mar Syst 15(1-4):139-148

Mason NW, Mouillot D, Lee WG, Wilson JB (2005) Functional richness, functional evenness and functional divergence: the primary components of functional diversity. Oikos 111(1):112-118

Massicotte P, Frenette JJ, Proulx R, Pinel-Alloul B, Bertolo A (2014) Riverscape heterogeneity explains spatial variation in zooplankton functional evenness and biomass in a large river ecosystem. Landsc Ecol 29(1):67-79 
Mouchet MA, Villéger S, Mason NW, Mouillot D (2010) Functional diversity measures: an overview of their redundancy and their ability to discriminate community assembly rules. Funct Ecol 24(4):867-876

Nebaeus M (1984) Algal water-blooms under ice-cover: with 1 figure and 2 tables in the text. Int Ver Theor Angew Limnol 22(2):719-724

Niswati A, Murase J, Kimura M (2005) Effect of application of rice straw and compost on the bacterial communities associated with Moina sp. in the floodwater of a paddy soil microcosm: estimation based on DGGE pattern and sequence analyses. Soil Sci Plant Nutr 51(4):565-571

O'neil JM, Davis TW, Burford MA, Gobler CJ (2012) The rise of harmful cyanobacteria blooms: the potential roles of eutrophication and climate change. Harmful Algae 14:313-334

Oksanen J, Blanchet FG, Kindt R, Legendre P, Minchin PR, O'hara RB et al. (2013) Package 'vegan'. Community ecology package, version, 2(9)

Ooms-Wilms AL (1997) Are bacteria an important food source for rotifers in eutrophic lakes? J Plankton Res 19(8):1125-1141

Paerl HW, Huisman J (2008) Blooms like it hot. Science 320(5872):57-58

Paerl HW, Otten TG (2013) Harmful cyanobacterial blooms: causes, consequences, and controls. Microb Ecol 65(4):995-1010

Paerl HW, Fulton RS, Moisander PH, Dyble J (2001) Harmful freshwater algal blooms, with an emphasis on cyanobacteria. Sci World J 1:76-113

Petchey OL, Gaston KJ (2006) Functional diversity: back to basics and looking forward. Ecol Lett 9(6):741-758

Reissig M, Trochine C, Queimaliños C, Balseiro E, Modenutti B (2006) Impact of fish introduction on planktonic food webs in lakes of the Patagonian Plateau. Biol Conserv 132(4):437-447

Roche KF (1987) Post-encounter vulnerability of some rotifer prey types to predation by the copepod Acanthocyclops robustus. In: Rotifer Symposium IV. Springer, Dordrecht, pp. 229-233

Roff JC, Turner JT, Webber MK, Hopcroft RR (1995) Bacterivory by tropical copepod nauplii: extent and possible significance. Aquat Microb Ecol 9(2):165-175

Rott E (1981) Some results from phytoplankton counting intercalibrations. Schweiz Z Hydrol 43(1):34-62

Schmera D, Heino J, Podani J, Erôs T, Dolédec S (2017) Functional diversity: a review of methodology and current knowledge in freshwater macroinvertebrate research. Hydrobiologia 787(1):27-44

Serrania-Soto CR, Sarma SSS, Nandini S (2011) Studies on comparative population growth of some species of the rotifer Lecane (Rotifera). J Environ Biol 32(4):523

Smirnov NN (1962) Eurycercus lamellatus (OF Müller) (Chydoridae, Cladocera): field observations and nutrition. Hydrobiologia 20(3):280

Starkweather PL, Kellar PE (1983) Utilization of cyanobacteria by Brachionus calyciflorus: Anabaena flos-aquae (NRC-44-1) as a sole or complementary food source. In: Biology of Rotifers. Springer, Dordrecht, pp. 373-377

R Core Team (2018) R: a language and environment for statistical computing. R Foundation for Statistical Computing, Vienna. https://www.R-project.org/

Thompson PL, Shurin JB (2012) Regional zooplankton biodiversity provides limited buffering of pond ecosystems against climate change. J Anim Ecol 81(1):251-259

Tillmanns AR, Wilson AE, Pick FR, Sarnelle O (2008) Meta-analysis of cyanobacterial effects on zooplankton population growth rate: species-specific responses. Appl Limnol/Arch Hydrobiol 171(4):285-295

Tilman D (2001) Functional diversity. Encycl Biodiv 3(1):109-120

Tilman D, Isbell F, Cowles JM (2014) Biodiversity and ecosystem functioning. Annu Rev Ecol Evol 45:471-493

Vaughn CC (2010) Biodiversity losses and ecosystem function in freshwaters: emerging conclusions and research directions. Bioscience 60(1):25-35

Villéger S, Mason NW, Mouillot D (2008) New multidimensional functional diversity indexes for a multifaceted framework in functional ecology. Ecology 89(8):2290-2301

Wejnerowski L, Cerbin S, Dziuba MK (2015) Thicker filaments of Aphanizomenon gracile are more harmful to Daphnia than thinner Cylindrospermopsis raciborskii. Zool Stud 54(1):2

Wilk-Woźniak E (2019) An introduction to the 'micronet' of cyanoHABs: cyanobacteria, zooplankton and microorganisms. A review. Mar Freshwater Res.

Wilk-Wozniak E, Pociecha A, Bucka H (2001) Phytoplankton-zooplankton interactions, size relations and adaptive responses. A short review. Int J Ecohydrol Hydrobiol 4(1):511-517

Wilson JB (1990) Mechanisms of species coexistence: twelve explanations for Hutchinson's 'Paradox of the plankton': evidence from New Zealand plant communities. N Z J Ecol 13:17-42 
Wilson AE, Sarnelle O, Tillmanns AR (2006) Effects of cyanobacterial toxicity and morphology on the population growth of freshwater zooplankton: meta-analyses of laboratory experiments. Limnol Oceanogr 51(4):1915-1924

Woodward GUY (2009) Biodiversity, ecosystem functioning and food webs in fresh waters: assembling the jigsaw puzzle. Freshw Biol 54(10):2171-2187

Work KA, Havens KE (2003) Zooplankton grazing on bacteria and cyanobacteria in a eutrophic lake. J Plankton Res 25(10):1301-1306

Zöllner E, Santer B, Boersma M, Hoppe HG, Jürgens K (2003) Cascading predation effects of Daphnia and copepods on microbial food web components. Freshw Biol 48(12):2174-2193

Publisher's Note Springer Nature remains neutral with regard to jurisdictional claims in published maps and institutional affiliations. 